\title{
12
}

\section{SELF-DETERMINATION UNDER INTERNATIONAL LAW AND SOME POSSIBILITIES FOR AUSTRALIA'S INDIGENOUS PEOPLES}

Asmi Wood

\section{Introduction}

Indigenous peoples in Australia are not seeking full political independence (or external self-determination) but rather the right of Indigenous self-determination as spelled out in articles 3-15 of the United Nations Declaration on the Rights of Indigenous Peoples (UNDRIP). ${ }^{1}$ This chapter explores how this notion of self-determination has developed in international law and how it applies to Indigenous peoples in Australia. I have written this chapter from the standpoint that self-determination could and should apply in a regionally differentiated way as determined freely by each group in accordance with their own customs and traditions. ${ }^{2}$ I will illustrate ways that Australia's approach to Indigenous self-determination has been and is still affected by the institutions of Australia’s federation. 
First, I show how Australia's dualistic approach to international legal obligations influences the domestic implementation of self-determination. Second, I examine the legal lacuna that have arisen from the interactions between Australia's constitutionally entrenched notion of terra nullius and Australia's common law and legislative recognition of Indigenous people. ${ }^{3}$ Third, I will examine the evolution of the concept of selfdetermination, with particular attention to the meanings of 'peoples' and 'self-determination' in international law. I will conclude by considering the prospects for self-determination for Indigenous peoples in Australia.

\section{Dualism: International law in Australia}

'Dualism', as it applies in Australia, can be explained by citing High Court of Australia Justice Anthony Mason:

It is a well settled principle of the common law that a treaty not terminating a state of war has no legal effect upon the rights and duties of Australian citizens and is not incorporated into Australian law on its ratification by Australia. ${ }^{4}$

International law is not self-effecting. After Australia ratifies an instrument of international law, the Parliament of Australia must then decide whether to incorporate this instrument to give domestic effect to its provisions. For example, Australia signed the International Convention on the Elimination of All Forms of Racial Discrimination on 13 October 1966, but it was not until 1975 that the Australian Parliament legislated the Racial Discrimination Act to implement Australia's obligations under that convention. Below, I will describe Australia's approach to instruments of international law that codify the right of self-determination. First, it is necessary to examine the implications of 'dualism'.

Dualism affects the analysis of self-determination in this chapter in two ways. First, self-determination is largely a creature of international law, but Australian law does not automatically recognise international law concepts deriving in the international plane. For international law that is not already a part of the broader common law or unambiguously

3 Mabo v Queensland (No 2) (1992) 175 CLR 1.

4 Koowarta v Bjelke-Petersen (1982) 153 CLR 168, 224-25 (per Mason J). 
part of customary international law to be binding under Australian law, the parliament must decide whether to incorporate these international obligations into domestic law, as I have explained. ${ }^{5}$

Second, Australia is not a unitary legal or political entity but a federation, so the six states retain plenary power, and Section 106 of the Australian Constitution preserves state constitutions. States' plenary powers include jurisdiction over land and inland waters, likely to be material to selfdetermination for Indigenous people for whom land is significant. If the Australian Government wishes to bind state governments to take a certain approach to land rights that originate in the international plane, it has the power to do so. Under Section 51(xxix), the federal parliament has primary responsibility for external affairs, and it is empowered by the Constitution to enter into and incorporate international obligations into laws that could be made binding on the states and territories. Further, the Australian Constitution was amended by referendum in 1967 to give the Australian Government power to pass law in respect of 'the people of any race'; in the recent past, only Aboriginal and Torres Strait Islander people have been subject to laws enacted under this provision. If an Australian government has the constitutional power to make a law and thinks it is necessary to invalidate state law, to the extent of any inconsistency with federal laws, it has that power to do so under Section 109, thus enabling it to create national laws, including treaty-based laws with respect to land. ${ }^{6}$ While the Australian Capital Territory and the Northern Territory have been self-governing since 1989 and 1978, respectively, under Section 122, the federal parliament 'may make laws for the government of any [Australian] territory' - a very broad power that can negate territory laws, in effect allowing the federal parliament domestically to incorporate international obligations that can then apply nationally. ${ }^{7}$

Australian common law and this model of federation affect the way that Australia acts on its international obligations. A decision by the national government to act in accordance with an international instrument on

5 That is, opinio juris or that Australia must believe that it is legally bound (by a law through custom): Military and Paramilitary Activities in and against Nicaragua (Nicaragua v United States of America), Merits, International Court of Justice (ICJ) Reports 1986, 14, para. 176, 194, 237. Customary international law is binding on all nations: North Sea Continental Shelf, Judgment, ICJ Reports 1969, 3, para. 39, 77. See Higgins, Problems, 204.

6 Australian Constitution, s. 109, and s. 122 for matters related to territories.

7 For example, the rights created under the Rights of the Terminally Ill Act 1995 (NT) were negated by the federal parliament's Euthanasia Laws Act 1997 (Cth). 
Indigenous self-determination (such as the UNDRIP) could trigger political negotiations among Australian governments. This mediation of international law through Australia's domestic, intergovernmental politics may affect how self-determination will operate in practice. Conversely, and to avoid the heavy hand of the parliament, Indigenous people would like to ensure that the principles of the UNDRIP will frame future negotiations and would seek to maintain the integrity of the instrument and the spirit in which the UNDRIP was formulated.

The interaction between such a federal system and self-determination 'models' for Indigenous peoples in Australia is likely to give rise to separate agreements between Indigenous groups and between the different jurisdictions in the federation. Consequently, a number of different selfdetermination models may emerge from the interplay between the various Indigenous groups and federal, state, territory and international laws. Further, Indigenous traditional territories do not necessarily fall neatly within state or territory boundaries, potentially creating a conflict of laws between different Australian jurisdictions.

\section{Australian sovereignty: A legal question yet to be resolved}

At Possession Island, Cape York, on 22 August 1770, Captain James Cook claimed possession of what he called 'New South Wales' for the British Crown. Colonisation began in January 1788, with Britain's formation of a penal colony at Port Jackson. When the British Crown asserted sovereignty over the Australian continent, international law provided three separate grounds for the acquisition of territory: (a) conquest, (b) cession or (c) the settlement of an uninhabited tract of land. ${ }^{8}$

Apart from 'treaty' negotiations in 1835 between the Kulin people and settlers led by John Batman - the outcome of which the Crown refused to recognise as legitimate - Indigenous peoples have never negotiated with a view to possibly ceding territory. ${ }^{9}$ Further, in Australian legal doctrine, the British did not win sovereignty over the continent by conquest, even though at certain times the colonial governors in New South Wales

8 Mabo v Queensland (No 2) (1992) 175 CLR 1; Dodson, Bailey and Wood, 'Australia and International Protection'.

9 Attwood (with Doyle), Possession, 13-101. 
(in 1824) and in Van Diemen's Land (1828-32) declared martial law in response to armed Aboriginal resistance. ${ }^{10}$ If neither cession nor conquest was the basis of Britain's sovereignty, Australian law developed on the basis of what Andrew Fitzmaurice calls the 'enlarged notion of terra nullius' (that the continent, while not strictly uninhabited, was not populated by people capable of exercising sovereign power over it). ${ }^{11}$ British control over the continent was consistent with (c): the doctrine that the Aboriginal inhabitants did not live under a system of government and law. That is, Australian federal law until 1992 implicitly or explicitly denied the prior existence of a civilised human population on the continent, denying 'visibility' (or legal personality) to Indigenous peoples as the original sovereigns; instead, colonial law had treated Aboriginal and Torres Strait Islander peoples as British subjects whose rights could be (and were) limited by legislation. That Australia's colonial law was based on the legal fiction of 'terra nullius' was explicitly enunciated and rejected by the High Court in 1992, as factually and morally flawed and as a 'narrow and ... rigid' doctrinal basis for Australia's sovereignty. ${ }^{12}$

Although the High Court recognised that Australia was not terra nullius (negating 'settlement' as a lawful means of acquiring inhabited lands), it did not declare a substitute legal basis for Australia's claim of sovereignty, saying that the question of sovereignty was a matter outside the competence of a municipal court. ${ }^{13}$ This posture leaves no further domestic legal avenues for plaintiffs wanting to test the legality of Australian claims of sovereignty. Litigation and/or negotiations on questions of sovereignty and self-determination should be conducted on the international plane.

Further, in the absence of a treaty between Australia and the Indigenous peoples of Australia, the principle of uti possidetis holds that territory remains with its (original) possessor (i.e. Indigenous people, at the end of a conflict). ${ }^{14}$ Therefore, in the absence of an Australian common law theory as to how sovereignty was acquired, at international law Australia arguably remains under its original possessors. Their common law rights became 'visible' to Anglo-Australian law in 1992 when the High Court recognised customary law as a source of law for Indigenous peoples

10 Connor, The Australian, 58, 91. And see Reynolds, Aboriginal.

11 Fitzmaurice, Sovereignty, 328.

12 Mabo v Queensland (No 2) (1992) 175 CLR 1. See paragraph 12 of the joint judgment of Justices Deane and Gaudron.

13 Mabo v Queensland (No 2) (1992) 175 CLR 1, 2.

14 Steiner and Alston, International. 
in Australia. As the legal question of Australia's sovereignty remains unresolved, there is both an opportunity and a space for negotiations and discussions on self-determination without preconditions. Because there is no doctrinal answer to the question of how sovereignty was acquired, the principle of uti possidetis puts Indigenous Australians in a position to negotiate under international law.

Although this is not a relevant consideration for Indigenous peoples who have never ceded sovereignty, one objection by the Australian state to allowing disputes over Australian sovereignty to be resolved in the international plane is that such negotiations would diminish the Crown's own claim to sovereignty. However, and again while this is not directly relevant from an Indigenous perspective, there are other domains of law in which UN member states have voluntarily agreed to weaken their claims to absolute sovereignty - such as multilateral commercial treaties that give rights to corporations to litigate the policies and laws of nation-states. ${ }^{15}$ While acknowledging that claims over sovereignty and self-determination are complex matters, it is particularly for this reason that I suggest that these discussions are better if conducted under international law and that negotiations take place in the international plane. ${ }^{16}$

\section{Legal personality: Domestic and international}

Indigenous people have always maintained their own sense of who they are as sovereign peoples. This chapter is a critique of the common law in Australia and consequently does not examine the question of the recognition of the Australian state by Indigenous peoples. Australia, while initially denying their existence through the legal fiction of terra nullius has recently recognised their 'legal personality' that would now lawfully (under the common law) enable the Australian state to engage in such negotiations. The constitutive theory of recognition broadly holds in the realm of sovereigns, such that legal personality and its rights and obligations can only occur through mutual recognition. ${ }^{17}$ Recognition is a branch

15 See, for example, UNCITRAL (United Nations Commission on International Trade Law) Arbitration Rules, as revised in 2010, www.uncitral.org/uncitral/en/uncitral_texts/arbitration/2010 Arbitration_rules.html.

16 Wood and Gardiner, 'Identifying'.

17 See Lauterpacht, Recognition, xxxi. 
of international law administered by the executive. ${ }^{18}$ 'Recognition' of a 'People' in international law, however, is a complex issue with a broader technical discussion outside the scope of this chapter. ${ }^{19}$ How might recognition be effected under Australian law?

'Indigenous recognition' in Australia has gradually, over time, been effected under the law. The rescission, by referendum, of Section 127 of the Australian Constitution in 1967 is a striking example of a slow recognition of Indigenous people under Australian law. While Aboriginal people have been enumerated by various colonial administrations since the early nineteenth century, an administrative practice continuing under every federal census, the population data so generated could not be used (in the words of Section 127) to 'reckon the numbers of the people of the Commonwealth, or of a State or other part of the Commonwealth'. This section had not stopped governments from counting and estimating an 'Aboriginal population', but it had stopped them from including those numbers in the published tables of the 'Australian population'; their exclusion materially affected the calculation of the number of House of Representatives electorates in each state. One effect of the rescission of Section 127 was that, from 1968, when authorities compiled tables of the 'Australian population' the people known as 'Aborigines' and as 'Torres Strait Islanders' were now added to the nation's total; at the same time, governments continued to publish figures on the 'Aboriginal population'. ${ }^{20}$ Many Indigenous people welcome this revised approach (combining inclusion and distinction) as Australia's recognition of them as distinct populations within the Australian population - a step towards the recognition in the common law of their peoplehood in 1992.

From time to time, Australian prime ministers have used words that arguably recognise Aboriginal peoples and Torres Strait Islanders as 'peoples'. In 1988, Prime Minister Bob Hawke attended the annual Barunga Sport and Cultural Festival, hosted by the Jawoyn community. Galarrwuy Yunupingu and Wenten Rubuntja, chairs of the Northern and Central land councils, there presented Hawke with 'The Barunga Statement', a painted declaration of the aspirations of 'the Indigenous owners and occupiers of Australia'; the statement requested that the

18 Lauterpacht, Recognition, xxv. Alternatives, such as the declarative theory of recognition, are not considered here.

19 Lauterpacht, Recognition.

20 For the Australian Government's and others' reasoning in making these changes see Rowse and Smith, 'The Limits'. 
Australian Government and people 'recognise our rights'. Hawke's speech at the festival agreed to the statement's request for a treaty-making process. Prime Minister John Howard's government reiterated this recognition of Aboriginal and Torres Strait Islander peoples as the first inhabitants of the continent, and articulated it in an ultimately unsuccessful referendum in $1998 .{ }^{21}$

Under international law, prime ministers' words are significant. In the Eastern Greenland Case (1933), the Permanent Court of International Justice (PCIJ) held that a country is bound by the undertakings given by its Minister of Foreign Affairs (in this case, a Norwegian minister) speaking in his official capacity. ${ }^{22}$ Thus, the words used by a head of government must also have significant, if not binding, effect on the international plane, even if subsequent words (including from some of the leader's successors) do not explicitly reiterate that recognition. That is, even if these Australian leaders' actions do not honour their words, the utterance of the words of recognition reinforces their sense of obligation and hence opinio juris on Indigenous recognition under international law. Determining the exact point at which custom crystallises into law is now a matter for the International Court of Justice (ICJ), which replaced the PCIJ in 1946. Further, while precedent does not strictly apply in the ICJ, the PCIJ's decision in the 1933 Eastern Greenland Case is strongly indicative that, if litigated, the ICJ is likely to hold Australian leaders to their word. How such a case would be mounted is, however, a different issue. Fortunately, the existence of the notion of opinio juris allows groups such as Indigenous peoples with an emerging international legal personality to apply these concepts to states and to hold their leaders to their words even when litigation is not possible.

The executive (through parliament) has explicitly recognised Indigenous peoples in legislation - the Aboriginal and Torres Strait Islander Peoples Recognition Act 2013. The Act acknowledges that Aboriginal and Torres Strait Islander people are the first inhabitants of this nation; it includes a broad timeframe for the holding of the referendum on recognition in the Constitution, without anticipating what forms such recognition will take. This law confirms the common law notion that Indigenous

21 McKenna, 'The Need'. The fact that the referendum was not successful is not relevant to international law.

22 Legal Status of Eastern Greenland (Norway v Denmark), Judgement, 1933 Permanent Court of International Justice (PCIJ) (ser. A/B) No. 53 (5 April). 
peoples are 'peoples' for purposes of domestic Australia law, permitting the parliament lawfully to enter into negotiations with Indigenous peoples. ${ }^{23}$ However, under Australia's Westminster system, the parliament (at the executive's will) can also rescind this legislation. This is an issue for Indigenous people, as the various parties here live on the same land but only one of these parties - the Australian state - possesses military capacity to enforce its will.

Constitutional amendment would be a more secure and lasting way to recognise Aboriginal people and Torres Strait Islanders as 'peoples', and there is a 'recognition process' currently in train. Without constitutional recognition there is a significant gap between the common law, legislation and the Constitution. The significance of this lack of a comprehensive legal recognition of Indigenous Australian peoples under Australia's domestic law is that Indigenous people are vulnerable to the whims of the executive. These deficiencies in the domestic law have a minimal impact for international law considerations. ${ }^{24}$

Notwithstanding the absence of constitutional recognition of Aboriginal peoples and Torres Strait Islander peoples as 'peoples', which, as mentioned above, can have practical implications for Indigenous peoples, legislative recognition by the parliament and executive clearly and unambiguously satisfies the technical test of mutual recognition according to international law. That is, Australia has recognised that Aboriginal and Torres Strait Islander peoples have legal personality; consequently, each of these groups is 'a people' in the meaning of the Charter of the United Nations ('UN Charter'). ${ }^{25}$ As the ICJ said:

What [legal personality] does mean is that it [the body, in that case the UN but here Indigenous people] is a subject of international law and capable of possessing international rights and duties, and that it has capacity to maintain its rights by bringing international claims. ${ }^{26}$

23 Aboriginal and Torres Strait Islander Peoples Recognition Act 2013 (Cth).

24 Wood, 'Constitutional Recognition: A Case'; Wood, 'Constitutional Recognition and Racial Equality'. See also Article 27 (Internal law and observance of treaties) of the Vienna Convention on the Law of Treaties, 1155 UNTS 331, which prohibits states from using their domestic laws to avoid their international obligations.

25 United Nations, Charter of the United Nations. Approval by the Australian parliament: Charter of the United Nations Act 1945 (Cth).

26 Reparation for Injuries Suffered in the Service of the United Nations (Advisory Opinion) [1949] ICJ Rep, 180,183. 
For the purposes of Australian law and thus the Australian state, Indigenous Australians have the legal standing to negotiate treaties and to pursue selfdetermination in both the domestic and international planes. This chapter examines the notion of self-determination only. The broader content of these treaties is outside the scope of the chapter and is examined elsewhere. ${ }^{27}$ With international supervision, perhaps through the UN's Human Rights Commission or (preferably, but less likely) the ICJ, Indigenous Australians could pursue self-determination. ${ }^{28}$ Internationally supervised treaty processes, including the rights to self-determination, are the better, more secure option for Indigenous people because they offer a degree of protection from the absolute, unilateral control of the executive, the parliament and the perils of trusting a dualistic legal system. ${ }^{29}$

\section{The development of the putative 'right' to self-determination in international law}

The right of Indigenous peoples to self-determination has developed in international law since the Second World War. There was no reference to 'self-determination' in the Dumbarton Oaks proposals for the draft UN Charter in late $1944 .{ }^{30}$ As a result of pressure from the Soviet Union, however, the charter accepted at San Francisco in June 1945 refers to self-determination:

To develop friendly relations among nations based on respect for the principle of equal rights and self-determination of peoples, and to take other appropriate measures to strengthen universal peace. ${ }^{31}$

Further, with reference to promoting international economic and social cooperation, the charter says:

With a view to the creation of conditions of stability and wellbeing which are necessary for peaceful and friendly relations among nations based on respect for the principle of equal rights and self-determination of peoples, the United Nations shall promote:

27 Wood and Gardiner, 'Identifying'.

28 Wood, 'Constitutional Recognition: A Case'.

29 Article 2 of the Vienna Convention on the Law of Treaties, 1155 UNTS 331. While this Convention refers to states as parties, it is arguable that these provisions could by agreement between the parties apply to 'the Peoples' entering into and concluding the treaty.

30 Hula, 'Dumbarton'.

31 Article 1(2) UN Charter. 
a. higher standards of living, full employment, and conditions of economic and social progress and development;

b. solutions of international economic, social, health, and related problems; and international cultural and educational cooperation; and

c. universal respect for, and observance of, human rights and fundamental freedoms for all without distinction as to race, sex, language, or religion. ${ }^{32}$

The UN Charter does not refer to a 'right to self-determination' nor does it clarify who, beyond the charter's broad reference to 'Peoples' (i.e. a group right), is the subject referred to by the word 'self'.

After the UN commenced, the Soviets continued to present 'self-determination' as a 'right'. At the second session of the General Assembly, the Soviet delegation proposed that the following words be included in the Universal Declaration of Human Rights:

Each people and each nation has the right to national selfdetermination. A state which has responsibility for the administration of self-determining territories, including colonies, must ensure the realisation of that right, guided by the principles and goals of the United Nations in relation to the peoples of such territories. ${ }^{33}$

However, the members of the UN that were still colonial powers opposed these words, and so the Universal Declaration of Human Rights (1948) does not mention 'self-determination' of peoples.

In the 1940s, the concept of 'self-determination' was understood to apply to the anticipated process of decolonisation. That is, it was understood to refer to the 'external self-determination' that would be enabled by the formal withdrawal of imperial dominion from colonised territories. As the European empires receded and enabled the formation of new nations, this concept of 'self-determination' was reinforced. Seventeen newly independent states were present at the opening of the Fifteenth Session of the General Assembly in 1960. The effect was to intensify the UN's attention on the right of external self-determination, resulting in the 'Declaration on the Granting of Independence to Colonial Countries 
and Peoples' in December $1960 .{ }^{34}$ The Preamble and Article 2 of this declaration had a broad reference to self-determination and required all states to 'end colonialism in all its forms and manifestations'. ${ }^{35}$ This declaration did not receive unanimous support. Nine colonial member states, including Australia, abstained from this vote. Although Australia was an independent state, it cherished colonial connections, with a deep and enduring commitment to Britain, as demonstrated in its founding documents, language, parliamentary processes and conventions, and the judicial system that invokes the prayer of 'God save the Queen' (albeit the Queen of Australia) ${ }^{36}$ However, the anti-colonial mood was powerful within the UN in the 1960s, resulting in General Assembly Resolution 1803 (XVII) of 14 December 1962, 'Permanent Sovereignty Over Natural Resources' and Resolution 1514 of 14 December 1965, 'The Declaration on the Granting of Independence to Colonial Countries and Peoples'. In such resolutions, the General Assembly reaffirmed colonised peoples' right to self-determination.

In tracking the rapid evolution of international law, we must note the significance of some member nations' dissent from such resolutions: dissent means that the resolution ranks lower in the hierarchy of the sources of international law as set out in the Statute of the International Court of Justice. ${ }^{37}$ Unanimous adoption arguably reflects that a resolution codifies international custom and state practice, and so unanimous resolutions rank higher as a source of law. ${ }^{38}$ Conventions and covenants (when ratified or when they become customary law), on the other hand, are binding at international law. So it was significant that, in 1966, the UN General Assembly expanded the human rights regime founded on the Universal Declaration on Human Rights by producing new international agreements that included the International Covenant on Civil and Political Rights (ICCPR) and the International Covenant on Economic, Social

34 UN General Assembly, Resolution 1514 (XV) of 14 December 1960, UN Doc. A/RES/1514(XV). Adom Getachew has emphasised the discontinuity between the UN's 1945 agreement that 'selfdetermination' is a 'principle' and the 1960 resolution declaring 'self-determination' to be a 'right'. In Getachew's account, the 'reinvention' of self-determination as a 'right' was a hard-won victory for global (particularly African) anti-colonial diplomacy as it faced the persistent strength of the colonial powers in League of Nations and then United Nations affairs in the 1940s. Getachew, Worldmaking, Chapter Three.

35 UN General Assembly, Resolution 1514 (XV).

36 Wilson, International Law, 68.

37 Article 38 of the Statute of the International Court of Justice, the citation, 33 UNTS 993.

38 Article 38(1)(b) of the Statute of the International Court of Justice, the citation, 33 UNTS 993. 
and Cultural Rights (ICESCR). ${ }^{39}$ Article 1 of the ICCPR is identical to Article 1 of the ICESCR and they are known as Common Article 1. It declares the right to self-determination for all peoples:

Article 1.

1. All peoples have the right of self-determination. By virtue of that right they freely determine their political status and freely pursue their economic, social and cultural development.

2. All peoples may, for their own ends, freely dispose of their natural wealth and resources without prejudice to any obligations arising out of international economic co-operation, based upon the principle of mutual benefit, and international law. In no case may a people be deprived of its own means of subsistence.

3. The States Parties to the present Covenant, including those having responsibility for the administration of Non-SelfGoverning and Trust Territories, shall promote the realization of the right of self-determination, and shall respect that right, in conformity with the provisions of the Charter of the United Nations.

Steiner and Alston refer to the right to self-determination in Common Article 1 as 'one of the most influential, debated and contested provisions'. ${ }^{40}$ Member states sought to limit the meaning and scope of self-determination in Common Article 1 so that it applied only to countries under 'foreign domination' and so that the words did not apply to independent states. Their efforts strengthened the concept of the territorial integrity of nation-states recognised by the UN. ${ }^{41}$ Thus, in the evolution of the concept of self-determination, it has become both possible and important to distinguish external self-determination (the right of a people to independent statehood) from internal self-determination that does not challenge the territorial integrity of the nation-state (the right of peoples to self-determination in the UNDRIP). Indigenous peoples are relatively weak politically and demographically and, consequently, settle pragmatically for internal self-determination only.

39 UN General Assembly, International Covenant on Civil and Political Rights, 16 December 1966, United Nations Treaty Series, vol. 999, p. 171, accessed 29 August 2018, www.refworld.org/docid/3ae 6b3aa0.html. UN General Assembly, International Covenant on Economic, Social and Cultural Rights, 16 December 1966, United Nations Treaty Series, vol. 993, p. 3, accessed 29 August 2018, www.ref world.org/docid/3ae6b36c0.html.

40 Steiner and Alston, International, 527.

41 Hannum, Autonomy, 41. 
Fear of internal fracturing by states is understandable as the drafting of the covenants goes back to the mid-1950s, a time when many states had just received independence and others were still to become independent of the colonising power. For example, India had received political independence from Britain in 1949 and then immediately experienced the breakup of its territory as West Pakistan (renamed Pakistan from 1971) and East Pakistan (renamed Bangladesh from 1971). Sensitive to the threat of further fragmentation, India declared in 1979 that the words 'the right of self-determination' 'apply only to the peoples under foreign domination and that these words do not apply to sovereign independent States or to a section of a people or nation - which is the essence of national integrity'. ${ }^{42}$ More recently, the situation in ex-Yugoslavia is a reminder that the UN's member states do not want international law to be used to promote a general 'Balkanisation' of the globe. ${ }^{43}$ There remain instances of the tension between the principle of the territorial integrity of a member state and the principle of external self-determination, as distinct and relatively large minorities in some nation-states (such as the Catalan in Spain) seek political and/or economic independence.

As international law has developed, the UN has produced further statements that support the self-determination of peoples. In 1970, the Declaration on Principles of International Law Concerning Friendly Relations and Co-operation among States in Accordance with the Charter of the United Nations (Friendly Relations Declaration) imposed on states the authoritative interpretation of seven charter principles. Principle 5 of this declaration is the principle of equal rights and self-determination of peoples'. ${ }^{44}$ In 1970, the UN General Assembly adopted the Friendly Relations Declaration without vote and so this decision represents consensus on the interpretation of these principles. ${ }^{45}$ Professor James Crawford includes self-determination in a list of jus cogens (peremptory) norms. ${ }^{46}$ The significance of the inclusion of this particular right by a judge of the ICJ is that, in his view, no derogation is possible from the right to self-determination.

42 India's Reservation to the Common Article 1 [Dated 10 April 1979], United Nations Treaty Collection, Status of Treaties, treaties.un.org/Pages/ViewDetails.aspx?src=TREATY\&mtdsg_no=IV$3 \&$ chapter $=4 \&$ clang $=\_$en.

43 Tomuschat, Modern.

44 Declaration on Principles of International Law Concerning Friendly Relations and Co-operation among States in Accordance with the Charter of the United Nations, Adopted on 24 October 1970, A/RES/25/ 2625(XXV).

45 Lowe, International, 100.

46 United Nations, International Law Commission, The International, 246-47. 


\section{The development of the UNDRIP}

The UNDRIP is the result of years of diplomacy and research by the UN's Working Group on Indigenous Populations. ${ }^{47}$ The UN Human Rights Committee noted in 1982 that 'the precise contours under international law of the right of self-determination remain in a state of flux'. ${ }^{48}$ One reason for this flux, by then, was that new answers were being given to the question of who could be recognised as a 'minority'. In the 1970s, an international 'indigenous' lobby emerged within the broader UN bureaucracy, encouraged by the interest that the ECOSOC's (Economic and Social Council's) Sub-Commission on Prevention of Discrimination and Protection of Minorities expressed in 1971 in the problem of discrimination against Indigenous populations. While commissioning research, the subcommittee in 1982 also established a Working Group on Indigenous Populations (WGIP). The flexible working methods adopted by the WGIP enabled many Indigenous people to present their historical experiences as distinguishing them from ethnic, religious and other minorities. The WGIP produced a draft declaration that was referred to the Commission on Human Rights, which established another working group. This second working group met on 11 occasions. Progress was slow because of certain states' concerns regarding some key provisions of the declaration, such as Indigenous peoples' right to self-determination and the control over natural resources existing on Indigenous peoples' traditional lands. The final version of the declaration was adopted on 29 June 2006 by the 47-member Human Rights Council (the successor body to the Commission on Human Rights), with 30 member states in favour, 2 against, 12 abstentions and 3 absentees. The declaration was then referred to the General Assembly, which voted on the adoption of the proposal on 13 September 2007. ${ }^{49}$ Through these episodes in international diplomacy, the idea that there were specifically 'indigenous' groups with legitimate claims to self-determination became thinkable. ${ }^{50}$

47 While the issues of Indigenous and Tribal peoples were originally considered by the International Labour Organization (ILO) this chapter will not examine the resulting Conventions, as Australia refused to ratify both Convention 107 'Indigenous and Tribal Populations' (1957) and Convention 169 'Indigenous and Tribal Peoples' (1989).

48 UN Human Rights Commission, 'Civil and Political Rights: The Human Rights Committee: Fact Sheet no. 15 (rev. 1)', www.ohchr.org/Documents/Publications/FactSheet15rev.1en.pdf; Pomerance, Self-determination.

49 Adopted by the General Assembly on 13 September 2007 with four states voting against and 11 abstentions, www.un.org/press/en/2007/ga10612.doc.htm.

50 Pritchard, 'Working'; Reed, Indigenous. 
Australia had actively participated in the drafting of the UNDRIP and, along with some other colonial states, it significantly slowed the draft's evolution. When the resolution was put to vote in 2007, Australia voted against the UNDRIP and did so with three other countries: Canada, the United States of America and Aotearoa/New Zealand (all states that have a very similar colonial history to Australia). Australia subsequently endorsed the UNDRIP on 3 April 2009, reiterating that, as a declaration (as opposed to a convention or covenant) the UNDRIP was not binding. ${ }^{51}$ This claim is technically true in Australia on two grounds. As a declaration, in effect a resolution of the General Assembly, the instrument is not binding. ${ }^{52}$ Further, the instrument is not binding in Australia, as a dualistic nation, until incorporated into domestic law..$^{53}$

Incorporating the UNDRIP into domestic law would provide a level of certainty and a collective understanding, including to legal terms related to self-determination when treaty negotiations within Australia begin. Constitutional recognition of Indigenous people would also remedy the defect of the inconsistency of 'recognition' between the common law and the Constitution as discussed above. Domestic incorporation of the UNDRIP in its original form would provide recognition of internationally framed rights of Indigenous peoples in Australian courts.

51 Endorsed by the Australian Government on 3 April 2009; 'Chart of Australian Treaty Ratifications as of May 2012 - Human Rights at Your Fingertips', Australian Human Rights Commission, 14 December 2012, www.humanrights.gov.au/chart-australian-treaty-ratificationsmay-2012-human-rights-your-fingertips-human-rights-your.

52 Öberg, 'Legal'.

53 Indigenous people have argued that the UNDRIP codifies already existing international custom, which is binding on all nations. Australia does not accept this position as indicated by its vote against the adoption of the UNDRIP (Australia would not be able to vote against internationally accepted customary law). Further, while Indigenous peoples have a strong moral claim to their position the fact that the instrument (the UNDRIP) is a declaration and not a convention gives strength to the position of countries such as Australia, Canada, the US and Aotearoa/New Zealand. 


\section{The prospects for Australia}

It took about 10 years for the ICESCR and the ICCPR to receive the required number of ratifications and to enter into force in the international plane. ${ }^{54}$ Australia ratified the ICESCR in 1975 and the ICCPR in $1980 .{ }^{55}$ Australia included the ICCPR as a schedule to the Australian Human Rights Commission Act 1986 and so the ICCPR forms part of Australian domestic law. ${ }^{56}$ The ICCPR arguably provides a broad but untested legal basis for the pursuit of self-determination. The UN's Human Rights Commission says of the group right to self-determination granted in Common Article 1 that:

This right differs from the other Covenant rights in that it is a right expressly ascribed to 'peoples' rather than to individuals ... [I]t can safely be taken that a precondition for a full and genuine expression of self-determination on the part of a people is the enjoyment by its members in whole measure of the rights contained in the Covenant. ${ }^{57}$

However, actions by Australian governments both domestically and in the international plane have given reason to doubt Australia's commitment to self-determination. For example, after legislating the Aboriginal and Torres Strait Islander Commission (ATSIC) in 1989, the Australian Government extinguished it in two steps in 2004 and 2005. ATSIC - a body with specific executive powers, elected by Aboriginal and Torres Strait Islander adults - had been a substantial step towards self-determination. Further, in 1998, the Australian Government amended the Native Title Act 1993

54 ICESCR entered into force on 3 January 1976; Australia ratified the ICESCR on 10 December 1975: humanrights.gov.au/our-work/commission-general/international-covenant-economic-social-andcultural-rights-human-rights.

55 Department of Foreign Affairs, 'International Covenant on Economic, Social and Cultural Rights (New York, 16 December 1966), Entry into force generally: 3 January 1976; Entry into force for Australia: 10 March 1976', Australian Treaty Series 1976 No. 5 (Canberra: Australian Government Publishing Service).

Department of Foreign Affairs and Trade, 'International Covenant on Civil and Political Rights (New York, 16 December 1966), Entry into force generally (except Article 41): 23 March 1976; Entry into force for Australia (except Article 41): 13 November 1980; Article 41 came into force generally on 28 March 1979 and for Australia on 28 January 1993', Australian Treaty Series 1980 No. 23 (Canberra: Australian Government Publishing Service).

56 In Section 3 of the Australian Human Rights Commission Act 1986 (Cth), 'Covenant' is defined as the International Covenant on Civil and Political Rights. A copy of the English text of that Covenant is in Schedule 2, as that International Covenant applies in relation to Australia.

57 UN Human Rights Commission, Fact Sheet no. 15 (rev. 1). 
in ways that were calculated to appease non-Indigenous critics of native title. In 1998, the High Court held that the Australian Government's use of the 'race' power was not limited to legislation that parliament judged to be beneficial..$^{58}$ In 2006-07, the Australian Government amended the Aboriginal Land Rights (Northern Territory) Act 1976 unilaterally. ${ }^{59}$ The parliament's unilateral, lawful power to act against Indigenous interests within Australia, coupled with some examples of Australia's current record on self-determination above, show that Indigenous rights are not likely to improve without at least some general international supervision. Further, and without resiling from the broader call for international supervision, since Indigenous peoples will exercise this specific right to internal self-determination under the umbrella of domestic law and domestic courts, domestic incorporation of the international definitions of selfdetermination is crucial.

The UNDRIP's vision of self-determination does not fragment the nationstate; rather it explicitly articulates what internal self-determination means. If Australia is reluctant to incorporate the whole UNDRIP, incorporating into domestic law the provisions quoted below would arguably provide a reasonable, internationally accepted basis and common understanding for self-determination negotiations between Indigenous peoples, the Commonwealth and the states and territories (and not discounting other legal entities, which may wish to participate).

The UNDRIP preamble reiterates that:

The Charter of the United Nations, the International Covenant on Economic, Social and Cultural Rights and the International Covenant on Civil and Political Rights, as well as the Vienna Declaration and Programme of Action, affirm the fundamental importance of the right to self-determination of all peoples, by virtue of which they freely determine their political status and freely pursue their economic, social and cultural development, Bearing in mind that nothing in this Declaration may be used to deny any peoples their right of self-determination, exercised in conformity with international law... ${ }^{60}$

58 Kartinyeri v Commonwealth [1998] HCA 22; (1998) 195 CLR 337, 355.

59 Aboriginal Land Rights (Northern Territory) Amendment Act 2006 (Cth).

60 UN General Assembly, United Nations Declaration on the Rights of Indigenous Peoples. 
The UNDRIP then provides substance to the notion of self-determination:

Article 3

Indigenous peoples have the right of self-determination. By virtue of that right they freely determine their political status and freely pursue their economic, social and cultural development.

Article 4

Indigenous peoples, in exercising their right to self-determination, have the right to autonomy or self-government in matters relating to their internal and local affairs, as well as ways and means for financing their autonomous functions.

Article 5

Indigenous peoples have the right to maintain and strengthen their distinct political, legal, economic, social and cultural institutions, while retaining their rights to participate fully, if they so choose, in the political, economic, social and cultural life of the State.

Articles 3-5 provide a useful legal content to the expression of self-determination. Incorporated into domestic legislation, they would provide a common internationally recognised legal basis and a touchstone for the negotiation of self-determination for Indigenous peoples. Any possibility of domestic incorporation depends on the parliament taking an interest in the principle of Indigenous self-determination as defined by international law and, at present, this seems unlikely.

\section{Conclusion}

The international community and international law have come some way in recognising the group rights of Indigenous peoples to selfdetermination and to 'freely determine their political status and freely pursue their economic, social and cultural development ${ }^{6}{ }^{61}$ For the right fully to be realised in Australia, there is a further barrier: the necessity to incorporate the international obligations into domestic law.

The complexities of Australia's federal structure mean that the various treaties that result through different groups' expressions of selfdetermination will likely form a complex web of rights and obligations.

61 UNDRIP Preamble. 
On the other hand, the Australian political elite fears, as it did with native title, that potential litigation will clog up the courts, and that Australia's claims to sovereignty will be subject to the jurisdiction and supervision of international bodies.

Australia's dualistic approach has a detrimental effect on Indigenous peoples. The hierarchy of sources is mentioned here to highlight the weakness of Indigenous arguments in domestic law. Further, Australia has ratified very little of the international law explicitly spelling out Indigenous rights. ${ }^{62}$ On the other hand, Indigenous people can also rely upon general human rights instruments, which are part of Australian law, to strengthen their claims to a right to self-determination under international law. That is why I have argued for negotiations taking place in the international plane. Domestic incorporation of the relevant international law provisions on self-determination will also allow the higher domestic courts to help adjudicate disputes, having regard to the vast international law and literature on this matter. Failure to resolve matters within Australia in the first instance will still leave open the possibility of a resolution of the disputes in the international plane.

While international law in the eighteenth century enabled the British Crown to claim sovereignty over the Australian continent, as a colony of settlement, this claim has resulted in great historical wrongs. Contemporary international law and norms, as they have evolved over the last two centuries, are legal and political resources for arresting and reversing the processes of colonisation. It is possible for parliament to take steps in this direction by working in good faith with Indigenous peoples to identify and resolve the problems of self-determined groups.

Since 1949, Australian governments have slowly dismantled the statutory discriminations against Indigenous peoples, and in recent years more and more Indigenous peoples have acquired formal education, making the fight for Indigenous rights and equality a little more practical and realistic than has been the case in the past.

This has made it possible for Indigenous people to acquire the skills and knowledge to negotiate and slowly recover their lost rights dating back for two centuries or more. They are getting to the point where they can do this almost as equals (although without the vast financial resources available to the state and with the parliament's ability still, in the domestic plane, to

62 For example, the ILO's C169-Indigenous and Tribal Peoples Convention, 1989. 
discriminate explicitly against them under the law and the Constitution). Nonetheless, the law and public opinion are slowly evolving to recognise the truth of the existence and survival of First Nations Peoples in Australia.

Since the graduation of the first Indigenous person through an Australian university about 50 years ago, Indigenous people have gradually been receiving tertiary and post-tertiary education in Western and international laws and ways, although there is still a long way to go in achieving population parity in this regard. Nonetheless, there is a critical mass of Indigenous Australians able to assert their rights as peoples. Subject to a few, very significant, remaining legal and constitutional barriers, they are on the threshold of being able to achieve their aim of exercising their peoplehood under the law.

Parties entering into good faith negotiations could right some of the most egregious wrongs of history. Recognising Indigenous peoples' rights truly and fully to self-determine and to evolve their cultures alongside the majoritarian Anglo-Australian law and culture will enrich, rather than diminish, our broader community.

\section{References}

Attwood, Bain (with Helen Doyle). Possession: Batman's Treaty and the Matter of History. Melbourne: The Miegunyah Press, 2009.

Bowring, Bill. 'Positivism versus Self-determination: The Contradictions of Soviet International Law'. In International Law on the Left: Re-examining Marxist Legacies, edited by Susan Marks. Cambridge: Cambridge University Press, 2008.

Connor, John. The Australian Frontier Wars, 1788-1838. Sydney: University of New South Wales Press, 2002.

Department of Foreign Affairs, Australian Treaty Series 1976 No. 5. Canberra: Australian Government Publishing Service, 1976.

Department of Foreign Affairs and Trade, Australian Treaty Series 1980 No. 23. Canberra: Australian Government Publishing Service, 1980.

Dodson, Michael, Peter Bailey and Asmi Wood. 'Australia and International Protection of Indigenous Rights'. In International Law in Australia, edited by D. Rothwell and E. Crawford, 139-64. Pyrmont, [NSW]: Thomson Reutuers, 2017. 
Fitzmaurice, Andrew. Sovereignty, Property and Empire, 1500-2000. Cambridge: Cambridge University Press, 2014.

Getachew, Adom. Worldmaking after Empire: The Rise and Fall of Self-determination. Princeton: Princeton University Press, 2019.

Hannum, Hurst. Autonomy, Sovereignty, and Self-determination: The Accommodation of Conflicting Rights. Philadelphia: University of Pennsylvania Press, 1966.

Higgins, Rosalyn. Problems and Process: International Law and How We Use It. Oxford: Clarendon Press; New York: Oxford University Press, 1994.

Hula, Erich. 'The Dumbarton Oaks Proposals'. Social Research 12, no. 2 (1945): $135-56$.

International Labour Organization (ILO). C169 - Indigenous and Tribal Peoples Convention, 1989. Jakarta: International Labour Office, 2007. Lauterpacht, Hersch, Sir. Recognition in International Law. Cambridge: Cambridge University Press, 1948.

Lowe, A. V. International Law. Oxford: Oxford University Press, 2007.

McKenna, Mark. 'The Need for a New Preamble to the Australian Constitution and/or a Bill of Rights'. Research Paper 12, 1996-97, Law and Bills Digest Group, Australian Parliament.

Öberg, Marko Divac. 'The Legal Effects of Resolutions of the UN Security Council and General Assembly in the Jurisprudence of the ICJ'. European Journal of International Law 16, no. 5 (1 November 2005): 879-906.

Pomerance, Michla. Self-Determination in Law and Practice. The Hague: Martinus Nijhoff, 1982.

Pritchard, Sarah. 'Working Group on Indigenous Populations: Mandate, Standard-Setting Activities and Future Perspectives'. In Indigenous Peoples, the United Nations and Human Rights, edited by S. Pritchard, 40-62. Annandale: the Federation Press, 1998.

Reed, Bradley. Indigenous Peoples and the State: The Struggle for Native Rights. DeKalb: Northern Illinois University Press, 2003.

Reynolds, Henry. Aboriginal Sovereignty: Three Nations, One Australia. Sydney: Allen \& Unwin, 1996.

Rowse, T. and L. Smith. 'The Limits of "Elimination" in the Politics of Population'. Australian Historical Studies 41, no. 1 (March 2010): 90-106. 
Steiner, Henry and Phillip Alston. International Human Rights in Context: Law, Politics, Morals. Oxford: Clarendon, 1996.

Tomuschat, T. Christian. Modern Law and Self Determination. Dordrecht/ Boston: Martinus Nijhoff Publishers, 1993.

United Nations. Charter of the United Nations, 1945. 1 United Nations Treaty Series XVI, 24 October 1945.

United Nations General Assembly. International Covenant on Civil and Political Rights, 16 December 1966, United Nations, Treaty Series, vol. 999, p. 171. Accessed 29 August 2018. www.refworld.org/docid/3ae6b3aa0.html.

United Nations General Assembly. International Covenant on Economic, Social and Cultural Rights, 16 December 1966. United Nations, Treaty Series, vol. 993, p. 3. Accessed 29 August 2018. www.refworld.org/docid/3ae6b36c0.html.

United Nations General Assembly. Resolution 1514 (XV) of 14 December 1960. UN Doc. A/RES/1514(XV).

United Nations General Assembly. United Nations Declaration on the Rights of Indigenous Peoples: Resolution / Adopted by the General Assembly, 2 October 2007. UN Doc. A/RES/61/295.

United Nations International Law Commission. The International Law Commission's Articles on State Responsibility: Introduction, Text, and Commentaries, compiled by James Crawford, 246-47. Cambridge: Cambridge University Press, 2002.

Wilson, Heather. International Law and the Use of Force by National Liberation Movements. New York: Clarendon Press, 1988.

Wood, Asmi. 'Constitutional Recognition: A Case for Less is More'. In It's Our Country: Indigenous Arguments for Meaningful Constitutional Recognition and Reform, edited by Marcia Langton and Megan Davis, 104-13. Melbourne: Melbourne University Press, 2016.

Wood, Asmi. 'Constitutional Recognition and Racial Equality'. In Constitutional Recognition, edited by Jennifer Nielsen, Simon Young and Jeremy Patrick, 103-28. Annandale, NSW: Federation Press, 2016.

Wood, Asmi and C. M. Gardiner. 'Identifying a Legal Framework for a Treaty between Australia's First Peoples and Others'. In Indigenous Governance, Indigenous Development: International Case Studies of Common Futures and Common Pathways, edited by D. E. Smith, A. Wighton, S. Cornell and R. Joseph, forthcoming 2020. 
This text is taken from Indigenous Self-Determination in Australia: Histories and Historiography, edited by Laura Rademaker and Tim Rowse, published 2020 by ANU Press, The Australian National University, Canberra, Australia.

doi.org/10.22459/ISA.2020.12 